\title{
Primary productivity as a control over soil microbial diversity along environmental gradients in a polar desert ecosystem
}

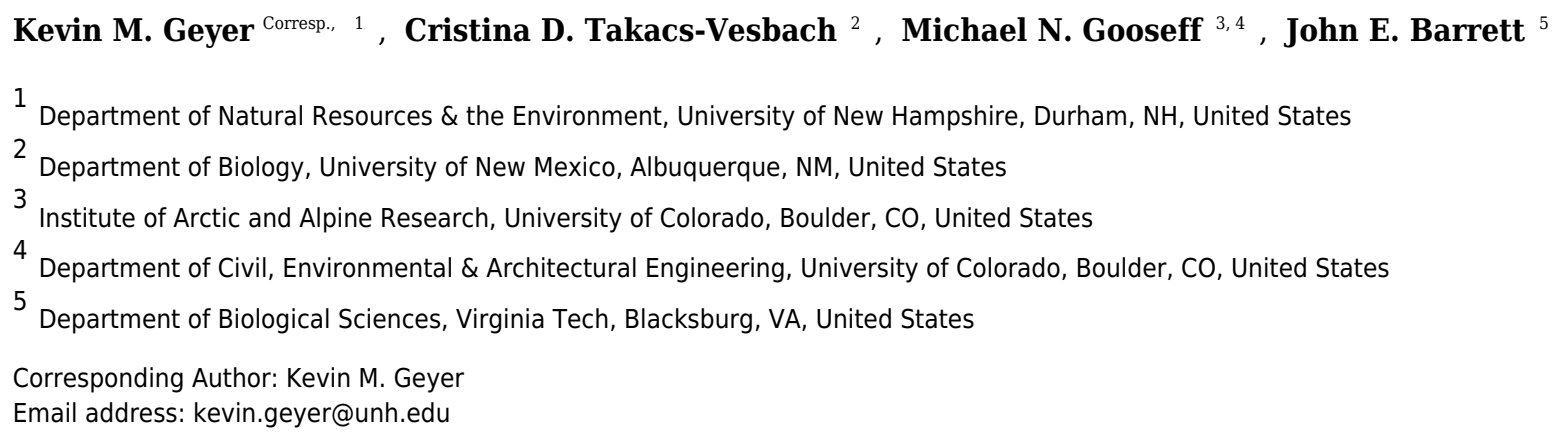

Primary production is the fundamental source of energy to foodwebs and ecosystems, and is thus an important constraint on soil communities. This coupling is particularly evident in polar terrestrial ecosystems where biological diversity and activity is tightly constrained by edaphic gradients of productivity (e.g., soil moisture, organic carbon availability) and geochemical severity (e.g. pH, electrical conductivity). In the McMurdo Dry Valleys of Antarctica, environmental gradients determine numerous properties of soil communities and yet relatively few estimates of gross or net primary productivity (GPP, NPP) exist for this region. Here we describe a survey utilizing pulse amplitude modulation (PAM) fluorometry to estimate rates of GPP across a broad environmental gradient along with belowground microbial diversity and decomposition. PAM estimates of GPP ranged from an average of $0.27 \mu \mathrm{mol} \mathrm{O} \mathrm{O}_{2} / \mathrm{m}^{2} / \mathrm{s}$ in the most arid soils to an average of $6.97 \mu \mathrm{mol} \mathrm{O} / \mathrm{m}^{2} / \mathrm{s}$ in the most productive soils, the latter equivalent to $217 \mathrm{~g} \mathrm{C} / \mathrm{m}^{2} / \mathrm{y}$ in annual net primary production assuming a 60 day growing season. A diversity index of four carbon-acquiring enzyme activities also increased with soil productivity, suggesting that the diversity of organic substrates in mesic environments may be an additional driver of microbial diversity. Overall, soil productivity was a stronger predictor of microbial diversity and enzymatic activity than any estimate of geochemical severity. These results highlight the fundamental role of environmental gradients to control community diversity and the dynamics of ecosystem-scale carbon pools in arid systems. 


\author{
Primary productivity as a control over soil microbial diversity along environmental gradients in a polar \\ desert ecosystem \\ Kevin M. Geyer ${ }^{1 \dagger}$, Cristina D. Takacs-Vesbach ${ }^{2}$, Michael N. Gooseff ${ }^{3,4}$ and J. E. Barrett ${ }^{5}$ \\ ${ }^{1}$ Department of Natural Resources \& the Environment, University of New Hampshire, Durham, New Hampshire \\ USA \\ ${ }^{2}$ Department of Biology, University of New Mexico, Albuquerque, New Mexico USA \\ ${ }^{3}$ Institute of Arctic and Alpine Research, University of Colorado, Boulder, Colorado USA \\ ${ }^{4}$ Department of Civil, Environmental \& Architectural Engineering, University of Colorado, Boulder, Colorado USA \\ ${ }^{5}$ Department of Biological Sciences, Virginia Polytechnic Institute and State University, Blacksburg, Virginia USA \\ †Email: kevin.geyer@unh.edu
}

\begin{abstract}
Primary production is the fundamental source of energy to foodwebs and ecosystems, and is thus an important constraint on soil communities. This coupling is particularly evident in polar terrestrial ecosystems where biological diversity and activity is tightly constrained by edaphic gradients of productivity (e.g., soil moisture, organic carbon availability) and geochemical severity (e.g. pH, electrical conductivity). In the McMurdo Dry Valleys of Antarctica, environmental gradients determine numerous properties of soil communities and yet relatively few estimates of gross or net primary productivity (GPP, NPP) exist for this region. Here we describe a survey utilizing pulse amplitude modulation (PAM) fluorometry to estimate rates of GPP across a broad environmental gradient along with belowground microbial diversity and decomposition. PAM estimates of GPP ranged from an average of 0.27 $\mu \mathrm{mol} \mathrm{O} / \mathrm{m}_{2}^{2} / \mathrm{s}$ in the most arid soils to an average of $6.97 \mu \mathrm{mol} \mathrm{O} / \mathrm{m}^{2} / \mathrm{s}$ in the most productive soils, the latter equivalent to $217 \mathrm{~g} \mathrm{C} / \mathrm{m}^{2} / \mathrm{y}$ in annual net primary production assuming a 60 day growing season. A diversity index of four carbon-acquiring enzyme activities also increased with soil productivity, suggesting that the diversity of organic substrates in mesic environments may be an additional driver of microbial diversity. Overall, soil productivity was a stronger predictor of microbial diversity and enzymatic activity than any estimate of geochemical severity. These results highlight the fundamental role of environmental gradients to control community diversity and the dynamics of ecosystem-scale carbon pools in arid systems.
\end{abstract}




\section{Introduction}

Primary production plays a fundamental role in controlling terrestrial foodwebs by making available the resources that regulate consumer productivity (Lindeman 1942; Tilman 1982; McNaughton et al. 1989) and shape community diversity (Waide et al. 1999; Judd et al. 2006). Rates of primary production also reflect the geochemical suitability of habitats for soil organisms (Chapin 1980), and thus much valuable information about the abiotic and biotic components of soil ecosystems can be inferred through knowledge of carbon fixation rates. Arid soils like those of the McMurdo Dry Valleys of Antarctica exemplify the tight coupling between ecosystem process rates and soil biological/geochemical properties. Here the landscape is dominated by alkaline $(\mathrm{pH}>9.0)$, saline (conductivity $>500 \mu \mathrm{S} / \mathrm{cm}$ ), dry (gravimetric moisture $<1 \%$ ) and low organic matter $(<0.03 \%$ organic $\mathrm{C}$ by weight) soils (Barrett et al. 2004) that support a very limited diversity of microfauna and no vascular plant or vertebrates species (Adams et al. 2006). However, seasonal wetting of stream and lake margins in this polar desert ameliorates the environmental severity and fosters dense cryptogamic mats of cyanobacteria and moss (Barrett et al. 2009). Such primary production reinforces the habitability of these hotspots for diverse microbial organotrophs through amendments of organic carbon (Treonis et al. 1999; Simmons et al. 2009; Geyer et al. 2013).

Despite a long history of researching environmental controls over Dry Valley soil diversity (Virginia and Wall 1999; Barrett et al. 2006b; Cary et al. 2010; Lee et al. 2012), efforts to measure rates of terrestrial gross or net primary production (GPP, NPP) in this system have been few. Rates of carbon fixation are near the levels of instrumental detection for gas exchange techniques and the growth rate of cryptogams does not lend itself to growthincrement based methods. Notable exceptions include the pioneering work of E. Imre Friedmann on cryptoendolithic lichens ( $\left.0.6 \mathrm{~g} \mathrm{C} / \mathrm{m}^{2} / \mathrm{y} \mathrm{NPP}\right)$ (Friedmann et al. 1993) and more recent surveys of coastal moss turfs ( $250 \mathrm{~g} \mathrm{C} / \mathrm{m}^{2} / \mathrm{y} \mathrm{NPP)} \mathrm{(Pannewitz} \mathrm{et} \mathrm{al.} \mathrm{2005)} \mathrm{and} \mathrm{riparian} \mathrm{Nostoc} \mathrm{cyanobacterial} \mathrm{mats} \mathrm{(} 20 \mathrm{~g} \mathrm{C} / \mathrm{m}^{2} / \mathrm{y} \mathrm{NPP}$ ) (Novis et al. 2007). The availability of new approaches to directly measure photosynthetic activity (e.g. pulse amplitude modulated (PAM) fluorometry) provides a unique opportunity to compare productivity estimates among analytical approaches and refine our understanding of the energetic basis of dry valley foodwebs.

Here we present the results of a field survey in the McMurdo Dry Valleys where the important ecological functions of productivity and decomposition were examined along a broad environmental gradient previously demonstrated as an important driver of biotic diversity and activity (Geyer et al. 2013). PAM fluorometry was used to estimate primary productivity while exoenzyme activity assays provide an indication of detrital pathways and the 
85 diversity of organic substrates. We discuss the overall significance of primary production within a low organic matter ecosystem towards influencing subsurface processes and community structure, as well as promising avenues

87 for using PAM fluorometry in conjunction with other techniques to constrain rates of primary production (and its sensitivity to environmental factors) within arid systems.

\section{Site Description and Methods}

90

\section{Site Description}

Surveys were conducted in Taylor Valley, a region well characterized by previous research within the larger McMurdo Dry Valleys, Antarctica. Soils of this region are a poorly weathered, dry-permafrost composed of $>90 \%$ sand-sized particles with ice cement occurring within $0.5 \mathrm{~m}$ of the surface (Ugolini and Bockheim 2008).

Salinity and $\mathrm{pH}$ are generally high, a consequence of limited vertical water movement through soil layers that results in the accumulation of weathered carbonates and aerially-deposited salts (Bockheim 1997). Low temperatures restrict photosynthesis within this region to an approximately 6-8 week austral summer period when 24-hour radiation elevates air and soil surface temperature $\left(10^{\circ} \mathrm{C}\right.$ and $25^{\circ} \mathrm{C}$ maxima, respectively) (Doran et al. 2002) and stimulates the melting of ice and snow to yield free water. Cryotolerant organisms such as cyanobacterial mats are reactivated and, in some cases, can resume photosynthesis and nitrogen fixation within minutes of rehydration along the soil surface (Vincent and Howard-Williams 1986; McKnight et al. 2007). A surprisingly diverse assemblage of microbes exists underground alongside a limited variety of metazoan invertebrates at higher trophic levels (Adams et al. 2006; Takacs-Vesbach 2010).

Communities of cyanobacteria, moss, lichens, and eukaryotic algae are responsible for primary production in this region and are often characterized by their niche habitat. For instance, a diversity of lithophytic cyanobacteria (e.g. families Nostocaceae and Oscillatoriaceae) are commonly divided into the operational categories hypolithic, endolithic, and epilithic according to the rock surface colonized (Broady 1996; Pointing et al. 2009). Cyanobacteria and fewer than ten species of moss frequently form dense cryptogamic mats along the wetted soil margins of streams, lakes, and snowpacks (Seppelt and Green 1998). A limited number of distinguishing morphological characteristics makes in-field identification challenging, and thus most mat-forming colonies are identified by morphotypes of color (e.g. black, orange, red) and/or physical location (e.g. wetted stream margin, submerged aquatic) (Broady 1996; McKnight et al. 2007). The dominant soil bacterial phyla in this region include many of the 
112 more common groups found worldwide, such as Actinobacteria, Acidobacteria, and Bacteroidetes (Cary et al.

113 2010).

114 Previous field surveys during the austral summer of 2010/2011 from Taylor and neighboring Wright

115 Valleys indicated that soils associated with an a priori productivity gradient (defined by surface density of microbial

116 mats) ranged over three orders of magnitude in chlorophyll $a$ concentrations $(0.30-270 \mu \mathrm{g} / \mathrm{g}$ dry material $)$. Across

117 this gradient was observed an increase in soil moisture, organic carbon, invertebrate abundance, microbial biomass

118 carbon, and diversity of bacteria (Geyer et al. 2013; Ball and Virginia 2014). The activity of two common carbon-

119 acquiring microbial exoenzymes ( $\alpha$ - and $\beta$-glucosidase) were also positively associated with soil productivity,

120 suggesting that productive habitats are more decompositionally active because of greater organic substrate

121 concentrations, enhanced activity or biomass of decomposers, or perhaps both.

122 Soil Sampling

123 Here we report the results of continued sampling along this productivity gradient performed during the

124 austral summer (January 2013) using five broad regions (Fig 1). These regions ranged from tens of meters to tens of

125 kilometers apart and consisted of common soil habitats found in Taylor Valley such as stream margins, the wetted

126 edge of snowpacks, and hyperarid soils (Table 1, Fig. 1). Although specific cryptogam identification was not

127 determined, moss and/or cyanobacteria mats frequently colonized more productive soils but appeared absent in

128 others. Three locations $\left(2.5 \mathrm{~m}^{2}\right.$ each) were chosen to capture the range of visually apparent surface production

129 within each of the five regions (15 locations overall); in so doing, soils along a productivity gradient were collected

130 from both within each region and across the greater Taylor Valley. Locations of high productivity contained dense

131 cryptogam mats up to $5 \mathrm{~cm}$ thick, while arid soils appeared barren and without conspicuous surface producers

132 (Supplement 1). PAM measurements were made on light-adapted surfaces at eight equidistant points within each

133 location following a gridded pattern. Triplicate soils were collected from within each location such that surface

134 cryptogams were stored separately as replicates and subsurface soils (to a depth of $5 \mathrm{~cm}$ per pit) combined to

135 produce one composite sample $(\sim 500 \mathrm{~g})$ per location. Ten grams of soil from this composite sample was

136 immediately preserved in a sucrose-lysis buffer for nucleic acid stabilization (Mitchell and Takacs-Vesbach 2008).

137 All samples were frozen at $-20^{\circ} \mathrm{C}$ (molecular samples $-80^{\circ} \mathrm{C}$ ) within 48 hours of collection. Field sampling was

138 permitted under McMurdo LTER NSF OPP grant 1115245.

139 Biogeochemical and Molecular Analyses 
141 from the acetone extract of dried surface soils (Castle et al. 2011; Geyer et al. 2013). Subsurface soil was $2 \mathrm{~mm}$

142 sieved and used for all subsequent analyses. Soil $\mathrm{pH}$ and electrical conductivity were measured from a 1:2 and 1:5

143 soil/water slurry, respectively, using standard procedures developed for this region (Nkem et al. 2006). Soil water

144 content was determined gravimetrically by oven-drying for $48 \mathrm{hr}$ at $105^{\circ} \mathrm{C}$. Total nitrogen (TN) was estimated from

$145 \sim 300 \mathrm{mg}$ of ground, dried, and acidified soil using a FlashEA 1112 NC Elemental Analyzer (CE Elantech,

146 Lakewood, NJ, USA). Chloroform-labile carbon was used as an indication of soil microbial biomass carbon (MBC)

147 where soil samples were fumigated with gaseous chloroform for five days under vacuum (Cheng and Virginia

148 1993). Paired fumigated and non-fumigated samples were then extracted with a $0.5 \mathrm{M} \mathrm{K}_{2} \mathrm{SO}_{4}$ solution and final

149 extracts analyzed for total organic carbon using a OI Model 1010 Total Organic Carbon Analyzer (OI Analytical,

150 College Station, TX, USA), where final chloroform-labile carbon was calculated as the difference between

151 fumigated and non-fumigated total organic carbon. Non-fumigated extracts were used as estimates of soluble soil

152 organic carbon (SOC).

153 Potential soil extracellular enzyme activity was assayed for five carbon and nitrogen acquiring enzymes

154 (Table 2) to characterize the diversity and magnitude of hydrolytic and oxidative decompositional pathways

155 (Sinsabaugh and Shah 2011). These measures were also examined as an index of organic matter complexity

156 (Tscherko et al. 2003). Hydrolytic activity was measured using $0.5 \mathrm{~g}$ soil incubations in the presence of labeled

157 substrates and $50 \mathrm{mM} \mathrm{NaHCO}_{3}$ buffer $(\mathrm{pH}=8.2)$ following the methods of Zeglin and others (2009). Oxidative

158 assays underwent similar treatment, although standards were created by reacting a known mass of L-3,4-

159 dihydroxyphenylalanine (L-DOPA) with horseradish peroxidase from which a standard curve (dilution series) of the

160 product was used to infer activity within field samples. For all assays, triplicate samples were incubated at room

161 temperature on a platform shaker $(250 \mathrm{rpm})$ for a minimum of $2 \mathrm{hr}$ and enzyme-induced fluorescence (hydrolytic

162 enzymes) measured by excitation $(365 \mathrm{~nm})$ and emission $(450 \mathrm{~nm})$ or light absorbance (oxidative enzyme) measured

163 by absorbance $(460 \mathrm{~nm})$ using a Tecan Infinite M200Pro plate reader (Tecan, Mannedorf, Zurich, Switzerland). In

164 addition to sample incubations, control (buffer only), substrate (substrate + buffer), and standard (standard + buffer)

165 references were analyzed to account for other sources of fluorescence. Final activity was normalized to sample

166 microbial biomass carbon (MBC) and expressed as activity (nmol of substrate cleaved) $\mathrm{h}^{-1} \mathrm{~g} \mathrm{MBC}^{-1}$. Organic

167 substrate breakdown is assumed to be entirely the result of microbially exuded enzymes. 

procedure, a conservative estimate of phylum level diversity (Thies 2007). DNA was extracted from soils using a modified cetyltrimethylammonium bromide $(\mathrm{CTAB})$ procedure involving a mixture of $1 \% \mathrm{CTAB}, 10 \%$ sodium dodecyl sulfate, phenol/chloroform/isoamyl alcohol $(\mathrm{pH}=7.5)$, lysozyme $(0.2 \mu \mathrm{g} / \mu \mathrm{L})$, and proteinase $\mathrm{K}(20 \mu \mathrm{g} / \mu \mathrm{L})$ with $\sim 0.75 \mathrm{~g}$ soil. PCR amplification took place in triplicate using a standard $2 \mu \mathrm{L}$ of diluted template, 0.025 units $/ \mu \mathrm{L}$ of Taq Hot Start Polymerase (Promega Corporation, Madison, WI, USA), and the universal bacterial primers 8F (5'-AGAGTTTGATCMTGGCTCAG-3') and 519R (5'-ACCGCGGCTGCTGGCAC-3'), the forward primer labeled with a 5' 6-FAM fluorophore (Integrated DNA Technologies, Coralville, IA, USA). Amplification reaction conditions were previously optimized for these soils by Geyer and others (2013). Successful amplifications

177 (13 of 15 samples) were digested with HaeIII (New England BioLabs, Ipswich, MA, USA) in triplicate for $3 \mathrm{hr}$ at

$17837^{\circ} \mathrm{C}$ following manufacturer's suggested protocols. Fragment separation/quantification took place in quadruplicate

179 with an ABI 3130xl Genetic Analyzer (Applied Biosystems, Carlsbad, CA, USA) and fragments binned using the

180 GeneMarker software AFLP protocol. Resulting sample profiles were standardized using the procedures outlined by

181 Dunbar (2001) to produce both a consensus profile among replicates and final normalization of all sample profiles

182 by total sample fluorescence.

183 PAM Fluorometry

184 A MINI-PAM (Walz) pulse amplitude modulated fluorometer was used to examine rates of surface 185 cryptogam production in-situ for 12 locations. The PAM fluorometer uses saturating light to induce a measurable 186 change in fluorescence directly proportional to the drop in photochemical quenching which results from the 187 instantaneous light-induced reduction of the photosystem II (PSII) electron transport chain. The key measurements 188 obtained from the PAM were effective quantum yield of PSII (YII) and electron transport rate (ETR). Additional 189 measures of photon flux density (photosynthetically active radiation, or PAR) and temperature at the cryptogam 190 surface were also recorded. YII is the proportion of incident light used to drive the photochemistry of photosynthesis 191 (Ritchie and Bunthawin 2010), while ETR is derived from the product of YII, PAR, and two factors which account

192 for a photon allocation factor between PSI and II (0.5) and a mean absorptance factor (0.84) previously described for 193 a variety of plants. 
195 ETR is thus an estimate of the rate of electron passage through PSII. Because four electrons pass through PSII per

196 oxygen molecule produced during photosynthesis, estimates of gross photosynthesis (or more specifically,

197 photosynthetic capacity) were calculated using (Figueroa et al. 2003; Ritchie and Bunthawin 2010):

$$
\operatorname{GPP}\left(\mu \mathrm{mol} \mathrm{O} 2 / \mathrm{m}^{2} / \mathrm{s}\right)=1 / 4 \times \operatorname{ETR}
$$

199 A strong linear relationship between ETR and gross photosynthesis has been previously demonstrated for Antarctic

200 mosses (Green et al. 1998, Masojidek et al. 2000) and has been extrapolated to the cryptogams surveyed here. Being

201 poikilohydric, the photosynthetic activity of Antarctic cryptogams is further constrained by moisture availability

202 (Schroeter et al. 2011). Our seasonal estimates of GPP should thus be interpreted as simplifications that will require

203 higher resolution moisture, temperature, and light conditions in order to be refined. All PAM measurements were

204 auto-corrected for background fluorescence of non-biological material (e.g. rocks).

205

206

207

208

209

210

211

212

213

214

215

\section{Results}

217

218

219

220

221

222

Data Analysis

Data analysis (correlation, t-tests, ANOVA, and simple/multiple linear regressions) was performed using SAS JMP. The normality of studentized residuals was examined and, if found significantly non-normal by ShapiroWilks test, either $\log _{10}$ (e.g. all enzyme activity values) or square-root transformed. Locations were clustered into three conservative productivity classes (e.g. low, intermediate, high) based on a k-means non-hierarchical clustering technique of soil moisture. Spearman correlation was used to assess pairwise interactions between all variables because of the presence of some nonlinear (monotonic) relationships. Multiple regression was performed using mixed stepwise selection of model parameters $(\alpha=0.15)$ that had variance inflation factors $<10$. Both TRFLP fragment abundances and enzyme activities were used in calculations of Shannon-Weiner diversity indexes. Enzyme diversity (Enz. H') calculations include the activity of AG, BG, NAG, and POX (Table 2) to provide a metric of carbon-acquiring enzyme activity from which the diversity of carbon substrates was inferred.

Soil characteristics of the 15 locations sampled resemble those observed in previous work conducted in hydrological margins of streams and lacustrine environments of the McMurdo Dry Valleys (Barrett et al. 2009; Geyer et al. 2013) and captured gradients of gravimetric water content ranging over an order of magnitude (range = $1.3-17.3 \%$; mean $=11.4 \%)$ and chlorophyll $a$ concentrations over two orders of magnitude $($ range $=0.02-2.84$ $\mathrm{ug} / \mathrm{g}$ dry material; mean $=0.88 \mu \mathrm{g} / \mathrm{g}$ dry material). Molar $\mathrm{C}: \mathrm{N}$ of total soil $($ range $=6.6-11.3 ;$ mean $=8.3)$ did not vary significantly with other measures of soil productivity. Correlational trends indicate that soil properties 
223 associated with physicochemical severity (e.g., electrical conductivity and pH) are positively correlated with one

224 another yet negatively correlated with properties of mesic, productive soils like chlorophyll $a$, microbial biomass

225 carbon, and bacterial (TRFLP) diversity (Table 3). Because of its importance as a driver of most soil parameters in

226 this arid system, soil moisture was chosen as a basis for clustering locations into three productivity zones (e.g. low,

227 intermediate, high) to examine variability at this scale. Strong differences exist among productivity zones for many

228 soil conditions such as $\mathrm{pH}$ and chlorophyll concentrations, and average values are reported per zone (Table 4).

229 PAM estimates of electron transport rate (ETR) were not significantly associated with soil moisture or

230 chlorophyll $a$, although a positive trend did exist. ETR was significantly related to both PAR and temperature levels

231 in a positive linear manner $\left(r^{2}=0.68, \mathrm{p}<0.001 ; r^{2}=0.24, \mathrm{p}<0.001\right.$; Fig. 2$)$. Although the relationship with PAR is

232 largely expected (given that light intensity is a factor in calculating electron transport rate), both relationships are

233 consistent in magnitude with the findings of Green and others $(1998 ; 2002)$ for photobionts.

234 Soil enzyme activity varied significantly by location. POX and LAP (lignin- and protein-degrading

235 enzymes, respectively) both exhibited a negative correlation with soil water content, as activity tended to be highest

236 in the most arid habitats (Table 4). Activity of AG and BG (starch- and cellulose-degrading enzymes, respectively)

237 had an opposite trend with the highest values found in productive soils, while NAG (chitin-degrading) activity

238 exhibited no trend. An index of overall enzyme diversity was calculated using the Shannon-Weiner equation to

239 highlight the relative change in evenness of carbon-acquiring enzyme activity (excluding protein-specific LAP), as

240 described by Tscherko and others (2003). Enzyme diversity had a significant positive relationship with soil moisture

$241\left(r^{2}=0.34 ; p<0.05\right)$ and significant negative relationship with $\mathrm{pH}\left(r^{2}=0.32 ; p<0.05\right)$. This result is a consequence

242 of high POX activity (as indicated by the relative enzyme activity; Fig. 3) in arid soils, which is gradually replaced

243 by a more even activity of all carbon-acquiring enzymes in productive soils. LAP activity did not correlate with total

244 nitrogen concentrations, or either nitrate-N or ammonium-N (Supplement Data). Multiple regression results suggest

245 soil water content as the driving force behind variation in most factors of biological diversity and activity (Fig 4).

246 Discussion

247 Environmental gradients are a key feature of arid environments often chosen for investigation as the

248 inferred mechanism underlying spatial patterns between productivity, for example, and diversity (Noy-Meir 1973).

249 While the diversity of microbial and metazoan communities in Antarctic terrestrial hotspots has been well

250 characterized (Simmons et al. 2009; Zeglin et al. 2011; Niederberger et al. 2015), process based measurements like 
251 primary productivity have received less attention. Here we contribute to this understanding of environmental

252 gradients by quantifying the rates of certain key functions that promote and reinforce the habitability of otherwise 253 hyperarid Antarctic soils.

254 PAM fluorometry was used to measure the rate of PSII electron transport rate (ETR), from which was 255 calculated gross primary production (GPP). GPP, organic carbon, and chlorophyll $a$ all peaked in the wettest soils 256 that support the densest cryptogam mats. Average GPP was $6.97 \mu \mathrm{mol} \mathrm{O}_{2} / \mathrm{m}^{2} / \mathrm{s}$ in these most productive soils, with a 257 maximum of $17.74 \mu \mathrm{mol} \mathrm{O} / 2 / \mathrm{m}^{2} / \mathrm{s}$ for one location. Assuming a $50 \%$ respiratory carbon loss during fixation (i.e. net 258 primary productivity, NPP; Schlesinger 1997) and 60 days of productivity per year (Burkins et al. 2001), this is 259 equivalent to an average NPP rate of $\sim 217 \mathrm{~g} \mathrm{C} / \mathrm{m}^{2} / \mathrm{y}$ with a maximum of $552 \mathrm{~g} \mathrm{C} / \mathrm{m}^{2} / \mathrm{y}$. Considering that some soils 260 in Taylor Valley contain concentrations of organic matter approaching $250 \mathrm{~g} \mathrm{C} / \mathrm{m}^{2}$ (Moorhead et al. 2003), mean 261 residence time (pool/flux) of carbon in highly productive zones would equal $\sim 2.2$ years. This is substantially lower 262 than the average residence time of decades to centuries estimated for soil organic matter in the broader Taylor 263 Valley landscape (Burkins et al. 2001; Barrett et al. 2005). Organic matter of productive dry valley soils is thus 264 primarily labile photosynthates of recent origin that are rapidly utilized by soil decomposers; this situation is 265 reversed with soil aridity, however, as soil carbon becomes increasingly dominated by recalcitrant substrates of 266 ancient provenance (Burkins 2001).

Average GPP for the least productive soils was $0.27 \mu \mathrm{mol} \mathrm{O} / 2 / \mathrm{m}^{2} / \mathrm{s}$. Again assuming that half of gross carbon and oxygen generation from GPP is consumed by respiration, this results in a NPP rate of $0.135 \mu \mathrm{mol}$

$269 \mathrm{O}_{2} / \mathrm{m}^{2} / \mathrm{s}$ ( or $0.135 \mu \mathrm{mol} \mathrm{CO} / \mathrm{m}^{2} / \mathrm{s}$ of autotrophic respiration). This falls within the range of total soil respiration rates 270 previously described for arid dry valley soils $\left(0.1-0.4 \mu \mathrm{mol} \mathrm{CO}_{2} / \mathrm{m}^{2} / \mathrm{s}\right.$; Burkins et al. 2001; Parsons et al. 2004; Ball 271 et al. 2009) and suggests that autotrophic respiration could constitute a substantial portion of total soil respiration 272 even in arid soils. The consistency of these findings should encourage researchers to couple PAM fluorometry with 273 soil $\mathrm{CO}_{2}$ flux measurements in future work to attempt distinguishing rates of GPP, NPP, and respiration for producer 274 communities at higher spatial and temporal resolution (Pannewitz et al. 2006). Recent evidence has also suggested 275 that $\mathrm{CO}_{2}$ efflux measurements from dry mineral soils in this region may be at least partially abiotic in origin 276 (Shanhun et al. 2012; Ball and Virginia 2015), which underscores the limit of $\mathrm{CO}_{2}$ flux measurements to adequately 277 depict (on its own) biological activity for this region. PAM fluorometry yields independent measures of primary 
278 production that can be used to further refine important properties of soil organic matter pools such as residence 279 times.

280 Interestingly, while GPP inferred from PAM fluorometry appears to provide a valuable measure of soil 281 productivity, it did not significantly correlate with chlorophyll levels (Table 3). This suggests that perhaps the better 282 measure of soil productivity may ultimately depend on the temporal scale of inference. Concentrations of soil 283 chlorophyll are thought to represent an integration of producer biomass accrual across days to weeks, from which 284 can be inferred regular moisture availability and stable periods of producer growth. ETR and GPP values, however, 285 provide rapid measures of producer performance under instantaneous light, temperature, and moisture conditions

286 that may not necessarily correlate with chlorophyll concentrations. The sensitivity of producers to rapid 287 environmental change, identification of potential production-limiting stressors, and repeated (non-invasive) long term measures of diel or even seasonal fluctuations in productivity of sample plots may be the best uses of PAM fluorometry. Indeed, previous work has applied PAM measures to reveal the effects of stress and damage to photosystem functioning (Schreiber 2004).

Patterns in enzyme activity across the productivity gradient indicate distinct shifts in the nature of detrital

292 pathways as well as organic matter pool complexity. Arid locations exhibited low evenness in an index of carbon-

293 acquiring enzyme diversity, as indicated by the overall dominance of phenol oxidase activity (Fig. 3). This evidence

294 suggests the soil organic matter pool in arid zones may be primarily composed of recalcitrant materials targeted by 295 oxidative enzymes. Although vascular (lignin-bearing) primary producers are absent from this system, recalcitrant 296 compounds may originate from the fatty acids and proteins of decomposing moss and lichen tissue (Beyer et al.

297 1995) deposited during ancient high-stands of a proglacial lake during the Last Glacial Maximum in Taylor Valley 298 (Hall et al. 2000). Such organic matter may be an important energetic source in the more hyperarid soils of this 299 region (Barrett et al. 2006a). In a broader sense the activity of oxidative enzymes worldwide has been found to be 300 greater in drier, more alkaline soils, perhaps a consequence of high mineral surface stability (Zeglin et al. 2009) or 301 higher phenol solubility under such conditions (Sinsabaugh 2010). LAP was also relatively more active in arid rather 302 than mesic locations, potentially indicating greater nitrogen limitation, reduced substrate (protein) availability, or 303 potentially a higher enzyme reactive efficiency at increased pH as suggested by Sinsabaugh and others (2008).

304 Recalcitrant organic substrates that we suspect to predominate in these arid soils, together with low nitrogen 
305 availability, likely contribute to the relatively low diversity and enzyme activity of microbial communities found in 306 such habitats.

307 The relative activity of all carbon-acquiring enzymes (i.e. Enz. H') indicated a more even carbon-acquiring

308 enzyme diversity within productive soils (Table 4). From this we infer higher diversity of organic compounds in

309 more productive regions, a logical conclusion considering the presence of greater producer biomass and diversity

310 (Orwin et al. 2006). Increased diversity of organic compounds may therefore be an additional factor behind the

311 greater diversity of organotrophic bacterial communities in productive locations (Grayston et al. 1998). Niche

312 differentiation among microorganisms for various substrates, particularly those that may be decomposed only via

313 specialized enzymatic pathways, may be a mechanism (along with increased resource availability) responsible for

314 increases in microbial diversity. Distinguishing the relative effects of resource quantity and quality remains an

315 important direction for further research to establish important drivers of microbial community diversity.

316 The estimates of primary production we report, even within drier habitats, provide evidence that $i n$-situ

317 carbon fixation is occurring widely across the McMurdo Dry Valley landscape with likely effects on subsurface

318 communities and biogeochemical rates. Environmental severity (soil pH, electrical conductivity) and resource

319 availability (soil moisture, organic carbon concentration) vary inversely along a gradient of soil productivity and

320 play important roles in determining biological diversity and activity, although moisture is the primary driver to

321 explain community structure and function (Fig. 4). Changing enzyme activity along this gradient also highlights

322 higher potential organic matter complexity in productive soils, an unforeseen factor that may promote microbial

323 diversity. Our estimates for annual NPP of the most productive dry valley soils, colonized by mixed cyanobacteria

324 and moss mats, indicate yields of $\sim 217 \mathrm{~g} \mathrm{C}^{\mathrm{m}} / \mathrm{y} / \mathrm{y}$, only slightly less than estimates of $250 \mathrm{~g} \mathrm{C} / \mathrm{m}^{2} / \mathrm{y}$ for nearby coastal

325 moss turfs (Pannewitz et al. 2005). We estimate annual NPP for the most arid soils (which dominate the dry valley

326 landscape) to be $\sim 8 \mathrm{~g} \mathrm{C} / \mathrm{m}^{2} / \mathrm{y}$, and thus an average NPP for Taylor Valley soil productivity would be much lower

327 than the global desert mean of $80 \mathrm{~g} \mathrm{C} / \mathrm{m}^{2} / \mathrm{y}$ (Waide et al. 1999). In spite of these low rates a diverse and active

328 organotrophic community persists here, a testament to the strength of interaction between ecosystem functioning

329 (production, decomposition), environmental conditions (resource quantity/quality), and biotic diversity.

330

331

332 
333

334

335

336

337

338

339

340

341

342

343

344

345

346

347

348

349

350

351

352

353

354

355

356

357

358

359

360

361

362

363

364

365

366

367

368

\section{Acknowledgments}

We would like to thank the Crary Laboratory staff at McMurdo Station for their assistance, as well as Raytheon

Company, Inc. and Petroleum Helicopters, Inc. for logistical support. We also thank Bobbie Niederlehner and

several Virginia Tech collaborators for their contributions towards data acquisition and analysis.

\section{References}

Adams BJ, Bardgett RD, Ayres E, Wall DH, Aislabie J, Bamforth S, Bargagli R, Cary C, Cavacini P, Connell L, Convey P, Fell JW, Frati F, Hogg ID, Newsham KK, O'Donnell A, Russell N, Seppelt RD, and Stevens MI. 2006. Diversity and distribution of Victoria Land biota. Soil Biology \& Biochemistry 38:3003-3018. 10.1016/j.soilbio.2006.04.030

Ball BA, and Virginia RA. 2014. The ecological role of moss in a polar desert: implications for abovegroundbelowground and terrestrial-aquatic linkages. Polar Biology 37:651-664. 10.1007/s00300-014-1465-2

Ball BA, and Virginia RA. 2015. Controls on diel soil CO2 flux across moisture gradients in a polar desert. Antarctic Science 27:527-534. 10.1017/s0954102015000255

Ball BA, Virginia RA, Barrett JE, Parsons AN, and Wall DH. 2009. Interactions between physical and biotic factors influence CO2 flux in Antarctic dry valley soils. Soil Biology \& Biochemistry 41:1510-1517. 10.1016/j.soilbio.2009.04.011

Barrett JE, Gooseff MN, and Takacs-Vesbach C. 2009. Spatial variation in soil active-layer geochemistry across hydrologic margins in polar desert ecosystems. Hydrology and Earth System Sciences 13:2349-2358.

Barrett JE, Virginia RA, Hopkins DW, Aislabie J, Bargagli R, Bockheim JG, Campbell IB, Lyons WB, Moorhead DL, Nkem JN, Sletten RS, Steltzer H, Wall DH, and Wallenstein MD. 2006a. Terrestrial ecosystem processes of Victoria Land, Antarctica. Soil Biology \& Biochemistry 38:3019-3034. 10.1016/j.soilbio.2006.04.041

Barrett JE, Virginia RA, Parsons AN, and Wall DH. 2005. Potential soil organic matter turnover in Taylor Valley, Antarctica. Arctic Antarctic and Alpine Research 37:108-117.

Barrett JE, Virginia RA, Wall DH, Cary SC, Adams BJ, Hacker AL, and Aislabie JM. 2006b. Co-variation in soil biodiversity and biogeochemistry in northern and southern Victoria Land, Antarctica. Antarctic Science 18:535-548. 10.1017/s0954102006000587

Barrett JE, Virginia RA, Wall DH, Parsons AN, Powers LE, and Burkins MB. 2004. Variation in biogeochemistry and soil biodiversity across spatial scales in a polar desert ecosystem. Ecology (Washington D C) 85:31053118. $10.1890 / 03-0213$

Beyer L, Sorge C, Blume HP, and Schulten HR. 1995. Soil organic matter composition and transformation in gelic histosols of coastal continental Antarctica. Soil Biology and Biochemistry 27:1279-1288. 10.1016/00380717(95)00054-i

Bockheim JG. 1997. Properties and classification of cold desert soils from Antarctica. Soil Science Society of America Journal 61:224-231. 
369

370

371

372

373

374

375

376

377

378

379

380

381

382

383

384

385

386

387

388

389

390

391

392

393

394

395

396

397

398

399

400

401

402

Broady PA. 1996. Diversity, distribution and dispersal of Antarctic terrestrial algae. Biodiversity and Conservation 5:1307-1335.

Burkins MB, Virginia RA, and Wall DH. 2001. Organic carbon cycling in Taylor Valley, Antarctica: quantifying soil reservoirs and soil respiration. Global Change Biology 7:113-125.

Cary SC, McDonald IR, Barrett JE, and Cowan DA. 2010. On the rocks: the microbiology of Antarctic Dry Valley soils. Nature Reviews Microbiology 8:129-138. 10.1038/nrmicro2281

Castle SC, Morrison CD, and Barger NN. 2011. Extraction of chlorophyll a from biological soil crusts: A comparison of solvents for spectrophotometric determination. Soil Biology \& Biochemistry 43:853-856. 10.1016/j.soilbio.2010.11.025

Chapin FS. 1980. The mineral nutrition of wild plants. Annual Review of Ecology and Systematics 11:233-260.

Cheng W, and Virginia RA. 1993. Measurement of microbial biomass in Arctic tundra soils using fumigationextraction and substrate-induced respiration procedures. Soil Biology and Biochemistry 25:135-141. 10.1016/0038-0717(93)90251-6

Doran PT, McKay CP, Clow GD, Dana GL, Fountain AG, Nylen T, and Lyons WB. 2002. Valley floor climate observations from the McMurdo dry valleys, Antarctica, 1986-2000. Journal of Geophysical ResearchAtmospheres 107:art13. 10.1029/2001jd002045

Dunbar J, Ticknor LO, and Kuske CR. 2001. Phylogenetic specificity and reproducibility and new method for analysis of terminal restriction fragment profiles of 16S rRNA genes from bacterial communities. Applied and Environmental Microbiology 67:190-197. 10.1128/aem.67.1.190-197.2001

Elberling B, Gregorich EG, Hopkins DW, Sparrow AD, Novis P, and Greenfield LG. 2006. Distribution and dynamics of soil organic matter in an Antarctic dry valley. Soil Biology \& Biochemistry 38:3095-3106. $10.1016 /$ j.soilbio.2005.12.011

Figueroa FL, Conde-Alvarez R, and Gomez I. 2003. Relations between electron transport rates determined by pulse amplitude modulated chlorophyll fluorescence and oxygen evolution in macroalgae under different light conditions. Photosynthesis Research 75:259-275. 10.1023/a:1023936313544

Friedmann EI, Kappen L, Meyer MA, and Nienow JA. 1993. Long-term productivity in the cryptoendolithic microbial community of the Ross Desert, Antarctica. Microbial Ecology 25:51-69.

Geyer KM, Altrichter AE, Van Horn DJ, Takacs-Vesbach CD, Gooseff MN, and Barrett JE. 2013. Environmental controls over bacterial communities in polar desert soils. Ecosphere 4:art127. 10.1890/es13-00048.1

Grayston SJ, Wang S, Campbell CD, and Edwards AC. 1998. Selective influence of plant species on microbial diversity in the rhizosphere. Soil Biology and Biochemistry 30:369-378. 10.1016/s0038-0717(97)00124-7

Green TGA, Schlensog M, Sancho LG, Winkler JB, Broom FD, and Schroeter B. 2002. The photobiont determines the pattern of photosynthetic activity within a single lichen thallus containing cyanobacterial and green algal sectors (photosymbiodeme). Oecologia (Berlin) 130:191-198. 
403

404

405

406

407

408

409

410

411

412

413

414

415

416

417

418

419

420

421

422

423

424

425

426

427

428

429

430

431

432

433

434

435

436

Green TGA, Schroeter B, Kappen L, Seppelt RD, and Maseyk K. 1998. An assessment of the relationship between chlorophyll alpha fluorescence and $\mathrm{CO} 2$ gas exchange from field measurements on a moss and lichen. Planta (Berlin) 206:611-618. 10.1007/s004250050439

Hall BL, Denton GH, and Hendy CH. 2000. Evidence from Taylor Valley for a Grounded Ice Sheet in the Ross Sea, Antarctica. Geografiska Annaler 82:275-303.

Judd KE, Crump BC, and Kling GW. 2006. Variation in dissolved organic matter controls bacterial production and community composition. Ecology 87:2068-2079.

Lee CK, Barbier BA, Bottos EM, McDonald IR, and Cary SC. 2012. The Inter-Valley Soil Comparative Survey: the ecology of Dry Valley edaphic microbial communities. Isme Journal 6:1046-1057. 10.1038/ismej.2011.170

Lindeman RL. 1942. The trophic-dynamic aspect of ecology. Ecology 23:399-418. 10.2307/1930126

Masojidek J, Grobbelaar JU, Pechar L, and Koblizek M. 2001. Photosystem II electron transport rates and oxygen production in natural waterblooms of freshwater cyanobacteria during a diel cycle. Journal of Plankton Research 23:57-66. 10.1093/plankt/23.1.57

McKnight DM, Tate CM, Andrews ED, Niyogi DK, Cozzetto K, Welch K, Lyons WB, and Capone DG. 2007. Reactivation of a cryptobiotic stream ecosystem in the McMurdo Dry Valleys, Antarctica: A long-term geomorphological experiment. Geomorphology 89:186-204. 10.1016/j.geomorph.2006.07.025

McNaughton S, Oesterheld M, Frank D, and Williams K. 1989. Ecosystem-level patterns of primary productivity and herbivory in terrestrial habitats. Nature (London) 341:142-144.

Mitchell KR, and Takacs-Vesbach CD. 2008. A comparison of methods for total community DNA preservation and extraction from various thermal environments. Journal of Industrial Microbiology \& Biotechnology 35:1139-1147. 10.1007/s10295-008-0393-y

Moorhead DL, Barrett JE, Virginia RA, Wall DH, and Porazinska D. 2003. Organic matter and soil biota of upland wetlands in Taylor Valley, Antarctica. Polar Biology 26:567-576. 10.1007/s00300-003-0524-x

Niederberger TD, Sohm JA, Gunderson TE, Parker AE, Tirindelli J, Capone DG, Carpenter EJ, and Cary SC. 2015. Microbial community composition of transiently wetted Antarctic Dry Valley soils. Frontiers in Microbiology 6:12. 10.3389/fmicb.2015.00009

Nkem JN, Virginia RA, Barrett JE, Wall DH, and Li G. 2006. Salt tolerance and survival thresholds for two species of Antarctic soil nematodes. Polar Biology 29:643-651. 10.1007/s00300-005-0101-6

Novis PM, Whitehead D, Gregorich EG, Hunt JE, Sparrow AD, Hopkins DW, Elberling B, and Greenfield LG. 2007. Annual carbon fixation in terrestrial populations of Nostoc commune (Cyanobacteria) from an Antarctic dry valley is driven by temperature regime. Global Change Biology 13:1224-1237. 10.1111/j.1365-2486.2007.01354.x

Noy-Meir I. 1973. Desert ecosystems: Environment and producers. Annual Review of Ecology and Systematics 4:2551. 
437

438

439

440

441

442

443

444

445

446

447

448

449

450

451

452

453

454

455

456

457

458

459

460

461

462

463

464

465

466

467

468

469

470

Orwin KH, Wardle DA, and Greenfield LG. 2006. Ecological consequences of carbon substrate identity and diversity in a laboratory study. Ecology (Washington D C) 87:580-593. 10.1890/05-0383

Pannewitz S, Green TGA, Maysek K, Schlensog M, Seppelt R, Sancho LG, Turk R, and Schroeter B. 2005. Photosynthetic responses of three common mosses from continental Antarctica. Antarctic Science 17:341352. $10.1017 / \mathrm{s} 0954102005002774$

Pannewitz S, Green TGA, Schlensog M, Seppelt R, Sancho LG, and Schroeter B. 2006. Photosynthetic performance of Xanthoria mawsonii C.W. Dodge in coastal habitats, Ross Sea region, continental Antarctica. Lichenologist (London) 38:67-81. 10.1017/s0024282905005384

Parsons AN, Barrett JE, Wall DH, and Virginia RA. 2004. Soil carbon dioxide flux in Antarctic dry valley ecosystems. Ecosystems 7:286-295. 10.1007/s10021-003-0132-1

Pointing SB, Chan YK, Lacap DC, Lau MCY, Jurgens JA, and Farrell RL. 2009. Highly specialized microbial diversity in hyper-arid polar desert. Proceedings of the National Academy of Sciences of the United States of America 106:19964-19969. 10.1073/pnas.0908274106

Ritchie RJ, and Bunthawin S. 2010. The use of pulse amplitude modulation (PAM) fluorometry to measure photosynthesis in a cam orchid, Dendrobium spp. (D. CV. Viravuth Pink). International Journal of Plant Sciences 171:575-585. 10.1086/653131

Schlesinger WH. 1997. The Biosphere: The carbon cycle of terrestrial ecosystems. In: Schlesinger, WH, ed. Biogeochemistry. San Diego: Elsevier Science, 127-165.

Schreiber U. 2004. Pulse-Amplitude-Modulation (PAM) Fluorometry and Saturation Pulse Method: An Overview. Chlorophyll a fluorescence: A signature of photosynthesis (BOOK).

Schroeter B, Green TGA, Pannewitz S, Schlensog M, and Sancho LG. 2011. Summer variability, winter dormancy: lichen activity over 3 years at Botany Bay, 77 degrees S latitude, continental Antarctica. Polar Biology 34:13-22. 10.1007/s00300-010-0851-7

Seppelt RD, and Green TGA. 1998. A bryophyte flora for Southern Victoria Land, Antarctica. New Zealand Journal of Botany 36:617-635.

Shanhun FL, Almond PC, Clough TJ, and Smith CMS. 2012. Abiotic processes dominate CO2 fluxes in Antarctic soils. Soil Biology \& Biochemistry 53:99-111. 10.1016/j.soilbio.2012.04.027

Simmons BL, Wall DH, Adams BJ, Ayres E, Barrett JE, and Virginia RA. 2009. Terrestrial mesofauna in aboveand below-ground habitats: Taylor Valley, Antarctica. Polar Biology 32:1549-1558. 10.1007/s00300-0090639-9

Sinsabaugh RL. 2010. Phenol oxidase, peroxidase and organic matter dynamics of soil. Soil Biology \& Biochemistry 42:391-404. 10.1016/j.soilbio.2009.10.014

Sinsabaugh RL, J. Shah. 2011. Ecoenzymatic stoichiometry of recalcitrant organic matter decomposition: the growth rate hypothesis in reverse. Biogeochemistry 102:31-43. 
471

472

473

474

475

476

477

478

479

480

481

482

483

484

485

486

487

488

489

490

491

492

493

494

495

496

497

498

499

500

501

502

503

504

Sinsabaugh RL, Lauber CL, Weintraub MN, Ahmed B, Allison SD, Crenshaw C, Contosta AR, Cusack D, Frey S, Gallo ME, Gartner TB, Hobbie SE, Holland K, Keeler BL, Powers JS, Stursova M, Takacs-Vesbach C, Waldrop MP, Wallenstein MD, Zak DR, and Zeglin LH. 2008. Stoichiometry of soil enzyme activity at global scale. Ecology Letters 11:1252-1264. 10.1111/j.1461-0248.2008.01245.x

Takacs-Vesbach CD. 2010. Factors promoting microbial diversity in the McMurdo Dry Valleys, Antarctica. Astrobiology series.

Thies JE. 2007. Soil microbial community analysis using terminal restriction fragment length polymorphisms. Soil Science Society of America Journal 71:579-591. 10.2136/sssaj2006.0318

Tilman D. 1982. Resource competition and community structure. Monographs in population biology.

Treonis AM, Wall DH, and Virginia RA. 1999. Invertebrate biodiversity in Antarctic dry valley soils and sediments. Ecosystems 2:482-492.

Tscherko D, Rustemeier J, Richter A, Wanek W, and Kandeler E. 2003. Functional diversity of the soil microflora in primary succession across two glacier forelands in the Central Alps. European Journal of Soil Science 54:685-696. 10.1046/j.1351-0754.2003.0570.x

Ugolini FC, and Bockheim JG. 2008. Antarctic soils and soil formation in a changing environment: A review. Geoderma 144:1-8. 10.1016/j.geoderma.2007.10.005

Vincent WF, and Howard-Williams C. 1986. Antarctic stream ecosystems - Physiological ecology of a blue-green algal epilithon. Freshwater Biology 16:219-233. 10.1111/j.1365-2427.1986.tb00966.x

Virginia RA, and Wall DH. 1999. How soils structure communities in the Antarctic dry valleys. Bioscience 49:973983.

Waide RB, Willig MR, Steiner CF, Mittelbach G, Gough L, Dodson SI, Juday GP, and Parmenter R. 1999. The relationship between productivity and species richness. Annual Review of Ecology and Systematics 30:257300. 10.1146/annurev.ecolsys.30.1.257

Zeglin LH, Dahm CN, Barrett JE, Gooseff MN, Fitpatrick SK, and Takacs-Vesbach CD. 2011. Bacterial Community Structure Along Moisture Gradients in the Parafluvial Sediments of Two Ephemeral Desert Streams. Microbial Ecology 61:543-556. 10.1007/s00248-010-9782-7

Zeglin LH, Sinsabaugh RL, Barrett JE, Gooseff MN, and Takacs-Vesbach CD. 2009. Landscape Distribution of Microbial Activity in the McMurdo Dry Valleys: Linked Biotic Processes, Hydrology, and Geochemistry in a Cold Desert Ecosystem. Ecosystems 12:562-573. 10.1007/s10021-009-9242-8 
505 Table 1. Description of the five sampling regions from which three locations (each) were chosen to collect samples.

506 Locations within each region were chosen to capture the range of soil primary productivity visually apparent.

507

\begin{tabular}{llll}
\hline Region & Landscape location & $\begin{array}{l}\text { Latitude/longitude } \\
\text { (decimal degree) }\end{array}$ & $\begin{array}{l}\text { Elevation (m } \\
\text { above sea level) }\end{array}$ \\
\hline 1 & Bonney Riegel, near Wormherder Creek & $-77.733333 / 162.320183$ & 294.5 \\
2 & Bonney Riegel, near Wormherder Creek & $-77.730383 / 162.334400$ & 259.9 \\
3 & Snowpack margin, near south shore Lake Hoare & $-77.637333 / 162.881200$ & 151.0 \\
4 & Upper Green Creek margin & $-77.624400 / 163.05403$ & 18.1 \\
& & & \\
& & $-77.615417 / 163.041450$ & 42.9 \\
\hline
\end{tabular}

508

509

510

511

512

513

514

515

516

517

518

519

520

521

522 
523 Table 2. Additional information for enzymatic assays of soils. Standards for the phenol oxidase assay were created

524 by reacting a known mass of L-3,4-dihydroxyphenylalanine substrate with a horseradish peroxidase. 4-MUB = 4-

525 methylumbelliferyl.

526

\begin{tabular}{llllll}
\hline Enzyme & Shorthand & Activity & Substrate & Standard & Target \\
\hline$\alpha$-glucosidase & AG & hydrolytic & $\begin{array}{l}\text { 4-MUB- } \alpha \text {-D- } \\
\text { glucopyranoside }\end{array}$ & 4-MUB & starch \\
$\beta$-glucosidase & BG & hydrolytic & $\begin{array}{l}\text { 4-MUB- } \beta \text {-D- } \\
\text { glucopyranoside }\end{array}$ & 4-MUB & cellulose \\
$\begin{array}{l}\text { N-acetyl- } \beta \text { - } \\
\text { glucosaminidase }\end{array}$ & NAG & hydrolytic & $\begin{array}{l}\text { 4-MUB-N-acetyl- } \beta-\mathrm{D}- \\
\text { glucosaminide }\end{array}$ & $4-\mathrm{MUB}$ & chitin \\
$\begin{array}{l}\text { phenol oxidase } \\
\text { POX }\end{array}$ & oxidative & $\begin{array}{l}\text { L-3,4- } \\
\text { dihydroxyphenylalanine }\end{array}$ & N/A & lignin \\
$\begin{array}{l}\text { leucine } \\
\text { aminopeptidase }\end{array}$ & LAP & hydrolytic & $\begin{array}{l}\text { L-leucine-7-amido-4- } \\
\text { methylcoumarin } \mathrm{HCl}\end{array}$ & $\begin{array}{l}7 \text {-amino-4- } \\
\text { methylcoumarin }\end{array}$ & protein \\
\hline
\end{tabular}

527

528

529

530

531

532

533

534

535

536

537

538

539

540

541

542

543

544

545 
546 Table 3. Spearman correlation matrix for soil properties. Electrical conductivity (EC, $\mu \mathrm{S} / \mathrm{cm})$; chlorophyll $a$ (Chla,

$547 \mu \mathrm{g} / \mathrm{g}$ dry soil); gravimetric moisture (\% Moist); soil organic carbon (SOC, mg/kg dry soil); total nitrogen (TN,

$548 \mathrm{mg} / \mathrm{kg}$ dry soil); microbial biomass carbon (MBC, mg/kg dry soil); TRFLP bacterial diversity (Bact. H'); $a$ -

549 glucosidase activity ( $\mathrm{AG}, \mathrm{nmol} / \mathrm{g} \mathrm{MBC} / \mathrm{hr}$ ); phenol oxidase activity (POX, nmol/g MBC/hr); diversity index of

550 activity for carbon-acquiring enzymes (Enz. H'); electron transport rate (ETR, $\left.\mu \mathrm{mol} / \mathrm{m}^{2} / \mathrm{s}\right)$.

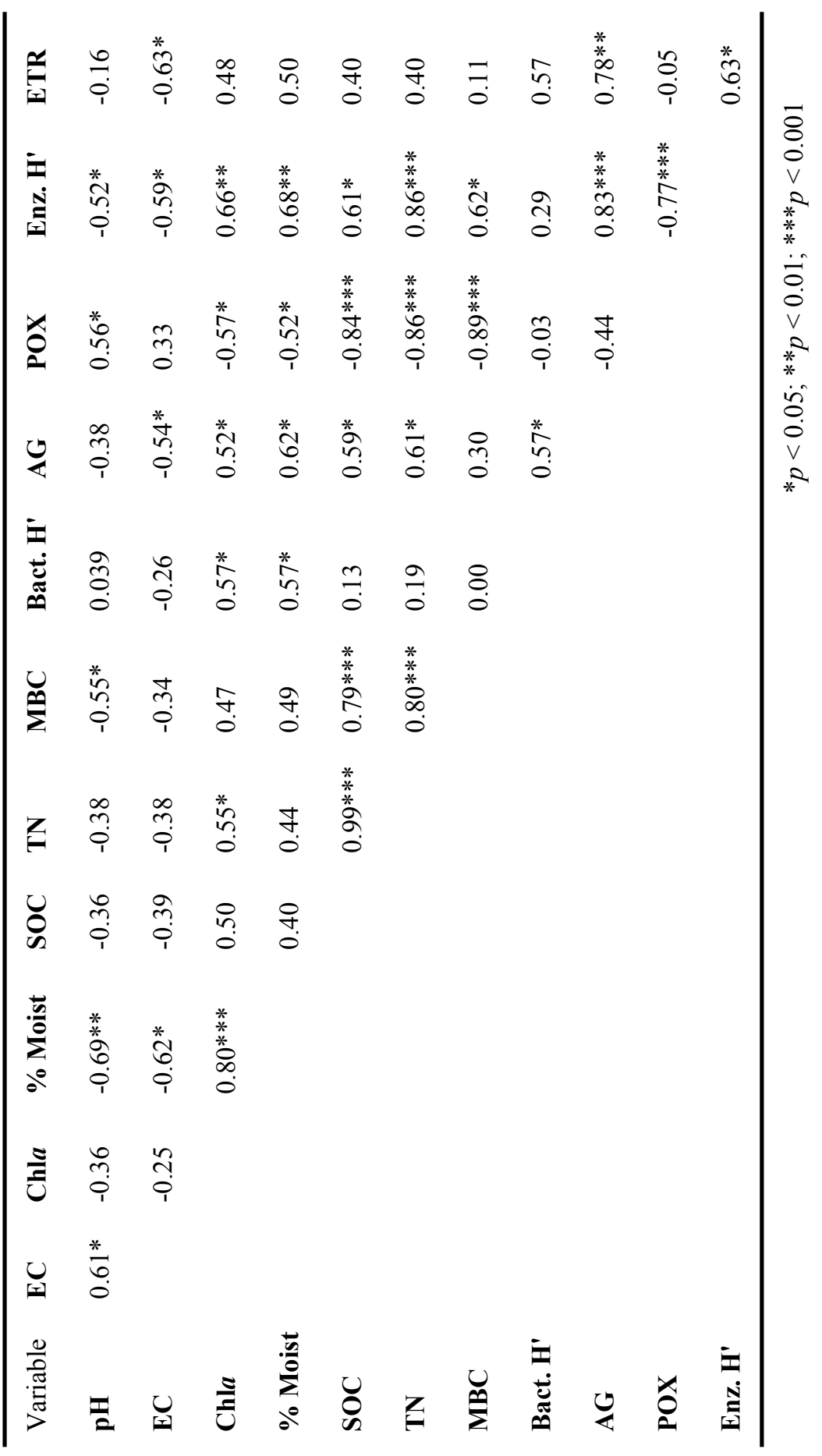


551 Table 4. Average (untransformed) edaphic properties for 15 soil habitats clustered by three productivity zones.

552 Standard error in parentheses except when missing data reduced $n<3$ (NA). Lowercase letters indicate significant

553 difference by ANOVA $(p<0.05)$. Electrical conductivity (EC, $\mu \mathrm{S} / \mathrm{cm})$; chlorophyll $a(\mathrm{Chl} a, \mu \mathrm{g} / \mathrm{g}$ dry soil);

554 gravimetric moisture (\% Moist); soil organic carbon (SOC, mg/kg dry soil); total nitrogen (TN, mg/kg dry soil);

555 microbial biomass carbon (MBC, mg/kg dry soil); TRFLP bacterial diversity (Bact. H'); $\alpha$-glucosidase activity (AG,

$556 \mathrm{nmol} / \mathrm{g} \mathrm{MBC} / \mathrm{hr}) ; \beta$-glucosidase activity (BG, nmol/g MBC/hr); N-acetyl- $\beta$-glucosaminidase activity (NAG, nmol/g

$557 \mathrm{MBC} / \mathrm{hr}$ ); phenol oxidase activity (POX, nmol/g MBC/hr); leucine aminopeptidase activity (LAP, nmol/g MBC/hr);

558 carbon-acquiring enzyme diversity (Enz. H'); electron transport rate (ETR, $\left.\mu \mathrm{mol} / \mathrm{m}^{2} / \mathrm{s}\right)$; gross primary production

$559\left(\mathrm{GPP}, \mu \mathrm{mol} \mathrm{O}{ }_{2} / \mathrm{m}^{2} / \mathrm{s}\right)$.

560

\begin{tabular}{|c|c|c|c|}
\hline \multirow[b]{2}{*}{ Variable } & \multicolumn{3}{|c|}{ Productivity Zone } \\
\hline & $\operatorname{Low}(n=3)$ & Intermediate $(n=7)$ & High $(n=5)$ \\
\hline $\mathrm{pH}$ & $8.77 \mathrm{a}(0.04)$ & $8.75 a(0.04)$ & $8.5 b(0.07)$ \\
\hline $\mathrm{EC}$ & $99.57 \mathrm{a}(35.76)$ & $54.6 \mathrm{ab}(7.49)$ & $26.56 b(6.14)$ \\
\hline Chla & $0.08 \mathrm{a}(0.05)$ & $0.73 \mathrm{ab}(0.23)$ & $1.56 \mathrm{~b}(0.39)$ \\
\hline$\%$ Moist & $3.94 \mathrm{a}(1.28)$ & $11.51 b(0.73)$ & $15.85 \mathrm{c}(0.56)$ \\
\hline $\mathrm{SOC}$ & $234.15 a(29.87)$ & $418.03 \mathrm{a}(82.88)$ & $438.71 \mathrm{a}(104.03)$ \\
\hline $\mathrm{TN}$ & $34.66 \mathrm{a}(3.98)$ & $55.34 \mathrm{a}(9.71)$ & $61.00 \mathrm{a}(13.26)$ \\
\hline $\mathrm{MBC}$ & $7.44 \mathrm{a}(2.23)$ & $12.93 \mathrm{a}(2.66)$ & $15.57 \mathrm{a}(3.49)$ \\
\hline Bact. H' & 4.06a (NA) & $4.23 \mathrm{a}(0.05)$ & $4.27 \mathrm{a}(0.05)$ \\
\hline $\mathrm{AG}$ & $6005 a(1987)$ & $9783 a(2279)$ & $14767 \mathrm{a}(3505)$ \\
\hline BG & $7233 a(988)$ & $15048 \mathrm{ab}(3020)$ & $25194 b(3621)$ \\
\hline NAG & $1633 a(415)$ & $2028 \mathrm{a}(272)$ & $2502 \mathrm{a}(316)$ \\
\hline POX & $2.51 \times 10^{7} \mathrm{a}\left(9.33 \times 10^{6}\right)$ & $1.13 \times 10^{7} \mathrm{a}\left(1.70 \times 10^{6}\right)$ & $1.00 \times 10^{7} \mathrm{a}\left(2.18 \times 10^{6}\right)$ \\
\hline LAP & $1.26 \times 10^{6} \mathrm{a}\left(2.30 \times 10^{5}\right)$ & $9.86 \times 10^{5} \mathrm{a}\left(1.77 \times 10^{5}\right)$ & $8.48 \times 10^{5} \mathrm{a}\left(1.30 \times 10^{5}\right)$ \\
\hline Enz. H' & $0.007 \mathrm{a}(0.009)$ & $0.020 \mathrm{ab}(0.006)$ & $0.039 b(0.007)$ \\
\hline ETR & $1.06 \mathrm{a}(\mathrm{NA})$ & $19.21 \mathrm{a}(9.14)$ & 27.86a (11.06) \\
\hline GPP & $0.27 \mathrm{a}(\mathrm{NA})$ & $4.80 \mathrm{a}(2.3)$ & $6.97 \mathrm{a}(2.8)$ \\
\hline
\end{tabular}

561

562

563

564 


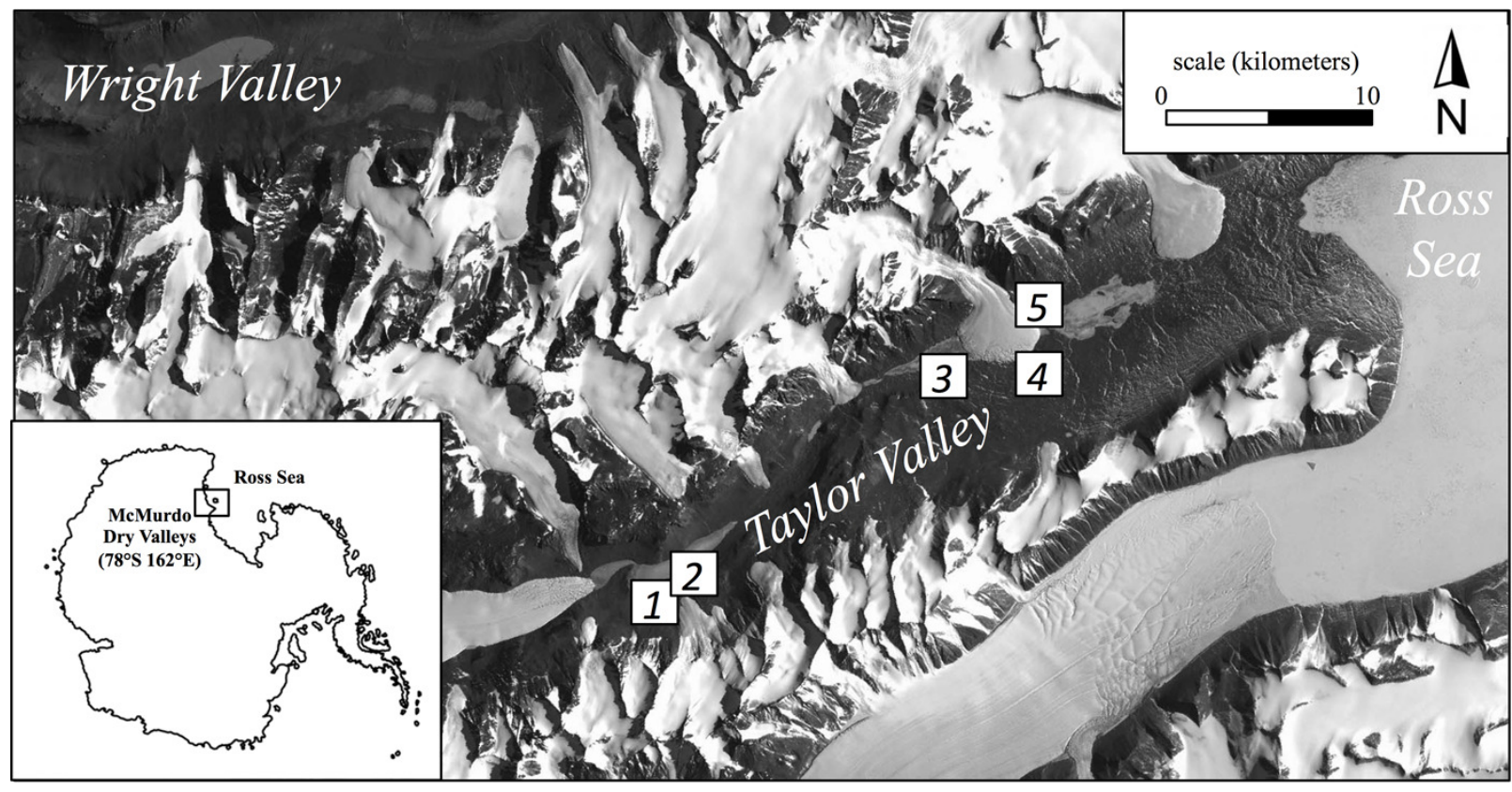

566

Fig. 1. Location of the five regional sampling sites in Taylor Valley of the McMurdo Dry Valleys, Antarctica.

567

568

569

570

571

572

573

574

575

576

577

578

579

580

581

582 

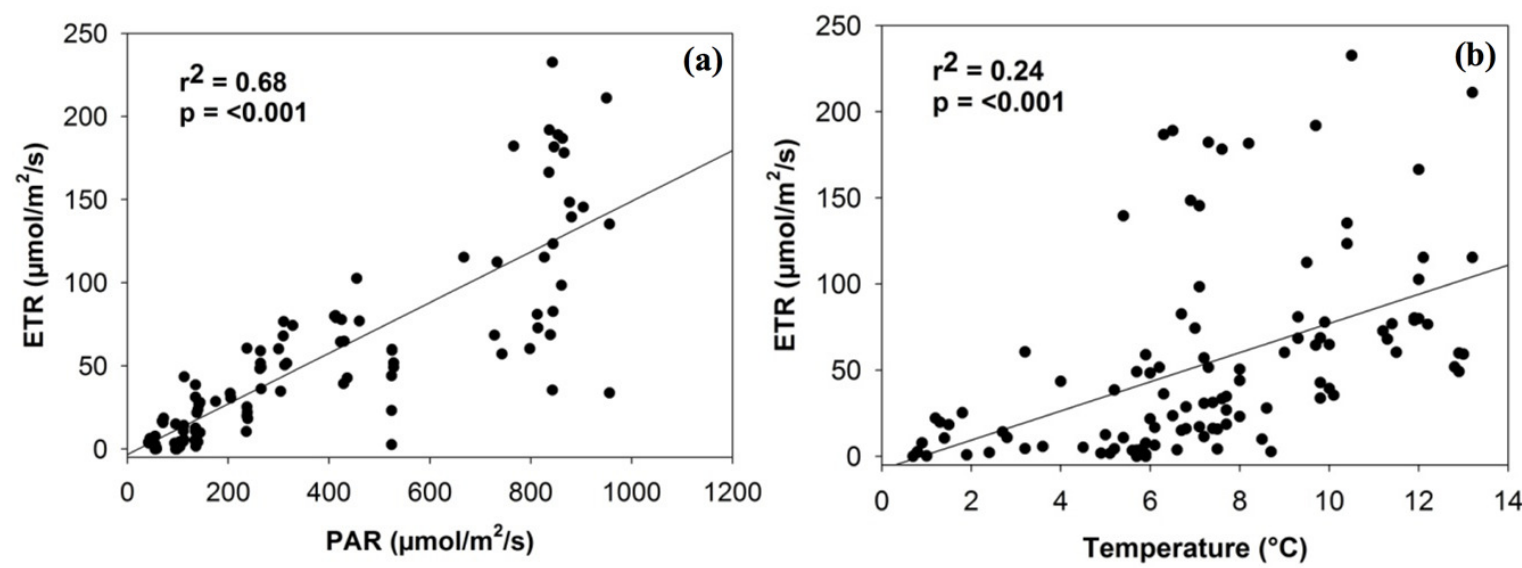

Fig. 2. Linear relationship between electron transport rate (ETR) and the density of photosynthetically active

585 radiation (PAR) (a) and temperature (b).

586

587

588

589

590

591

592

593

594

595

596

597

598

599

600

601

602 


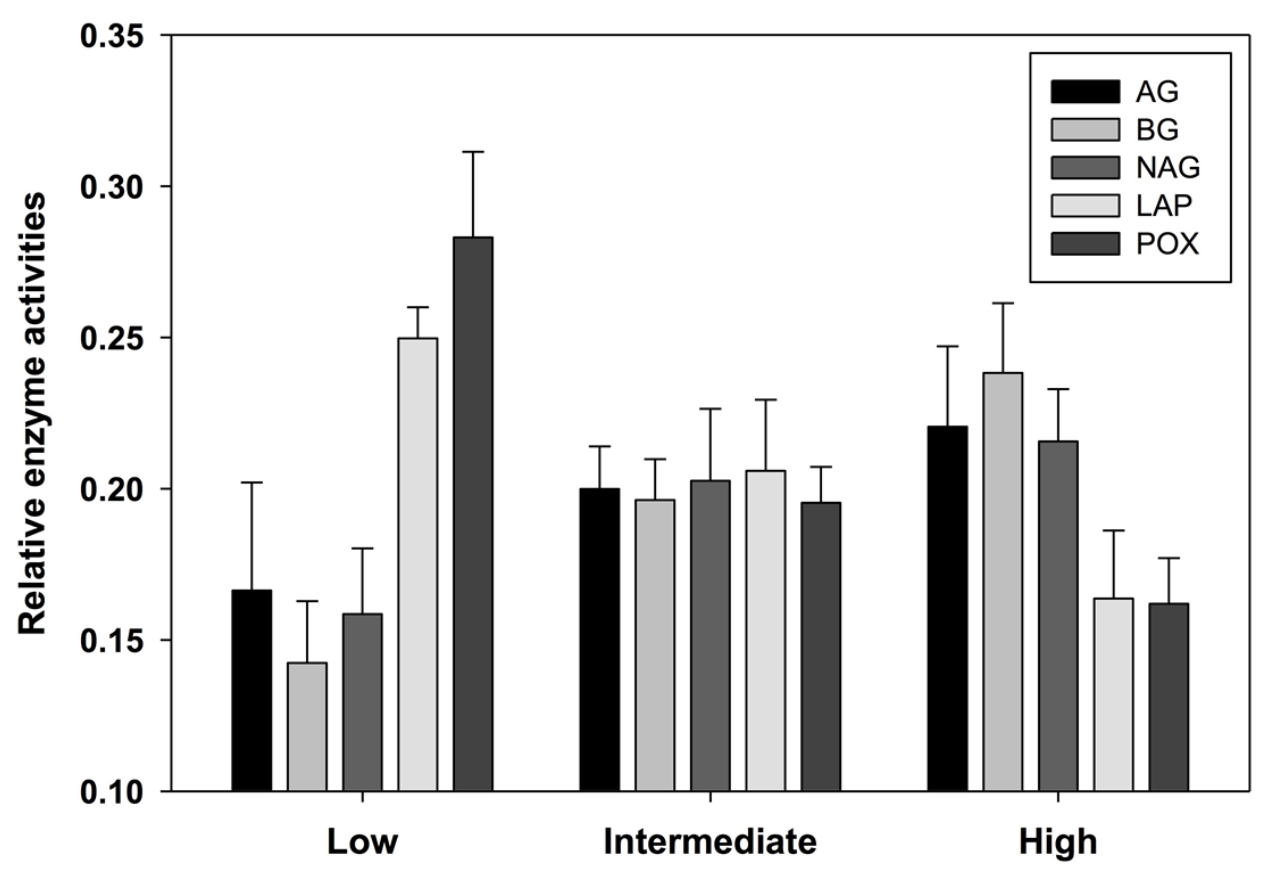

603

Fig. 3. Relative activity of five standardized ((x-mean)/standard deviation +3$)$ exoenzymes for sample locations clustered into three productivity classes by soil moisture content. The number of observations are $n=3$ (Low), $n=7$

606 (Intermediate), and $n=5$ (High). $\alpha$-glucosidase activity (AG, nmol/g MBC/hr); $\beta$-glucosidase activity (BG, $\mathrm{nmol} / \mathrm{g}$ $\mathrm{MBC} / \mathrm{hr}$ ); $\mathrm{N}$-acetyl- $\beta$-glucosaminidase activity (NAG, nmol/g MBC/hr); leucine aminopeptidase activity (LAP, nmol/g MBC/hr); phenol oxidase activity (POX, nmol/g MBC/hr).

609

610

611

612

613

614

615

616 
SLR Parameters $\left(r^{2}\right)$

\begin{tabular}{|c|c|c|c|c|c|}
\hline \multirow[b]{2}{*}{ Factors } & \multicolumn{4}{|c|}{ SLR Par: } & \multirow{2}{*}{ (a) } \\
\hline & \% Moist & Chla & pH & EC & \\
\hline AG & $0.36^{*}$ & 0.16 & 0.14 & $0.27^{*}$ & $\%$ Moist $(0.36)^{*}$ \\
\hline BG & $0.50 * *$ & $0.50 * *$ & 0.21 & $0.43 * *$ & $\%$ Moist $(0.50)^{* *}$ \\
\hline POX & $0.35^{*}$ & $0.31 *$ & 0.26 & $0.33^{*}$ & $\%$ Moist $(0.35)^{*}$ \\
\hline LAP & 0.14 & 0.21 & 0.24 & 0.09 & $\mathrm{pH}(0.24)$ \\
\hline Enz. H' & $0.34 *$ & $0.29 *$ & $0.32 *$ & $0.29 *$ & $\%$ Moist $(0.34)^{*}$ \\
\hline Bact. $\mathrm{H}^{\prime}$ & $0.34 *$ & 0.25 & 0.01 & 0.09 & $\%$ Moist, $\mathrm{pH}(0.67)^{* *}$ \\
\hline GPP & $0.39 *$ & 0.15 & 0.05 & $0.38^{*}$ & $\%$ Moist $(0.39)^{*}$ \\
\hline
\end{tabular}

(a)

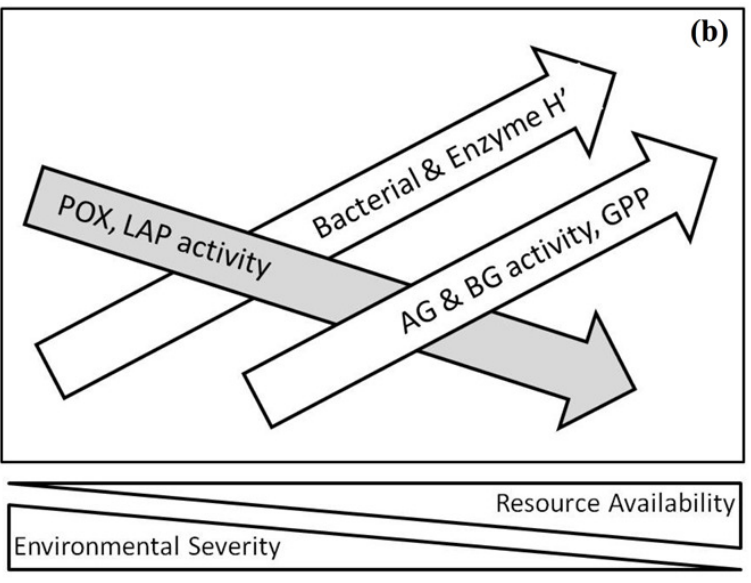

618 Fig. 4. Simple linear regression (SLR, $r^{2}$ ) results (a) of soil factors against parameters associated with resource

619 availability (e.g. \% gravimetric moisture, chlorophyll $a$ ) and environmental severity (e.g. pH, electrical

620 conductivity). Shaded cells indicate a negative relationship for simple regressions. Multiple linear regression (MLR,

$621 R^{2}$ ) results indicate parameter(s) that best predicts soil factors. Illustration of SLR results (b) along a hypothetical

622 environmental gradient. Gravimetric moisture (\% Moist); electrical conductivity (EC, $\mu \mathrm{S} / \mathrm{cm})$; chlorophyll $a(\mathrm{Chl} a$,

$623 \mu \mathrm{g} / \mathrm{g}$ dry soil) $\alpha$-glucosidase activity (AG, nmol/g MBC/hr); $\beta$-glucosidase activity (BG, nmol/g MBC/hr); phenol

624 oxidase activity (POX, nmol/g MBC/hr); leucine aminopeptidase activity (LAP, nmol/g MBC/hr); index of activity

625 for all carbon-acquiring enzymes (Enz. H'); TRFLP bacterial diversity (Bact. H'); gross primary production (GPP, $\left.626 \mu \mathrm{mol} \mathrm{O} / \mathrm{m}^{2} / \mathrm{s}\right)$. 